\title{
INFLUENCE OF LED RADIATION ON THE STAPHYLOCOCCUS AUREUS SENSITIVITY TO ANTIBIOTICS
}

\author{
V.V. Pantyo \\ Cand. Sci. (Biol.), Assoc. Prof. \\ Department of microbiology, virology,epidemiology \\ with the course Infectious Diseases, Medical faculty \\ Uzhhorod National University \\ 3 Narodna Sq., Uzhgorod, 88000, Ukraine \\ tel: +38 (066) 775-50-63 \\ e-mail: valerij.pantyo@uzhnu.edu.ua \\ ORCID 0000-0002-0207-3372
}

\author{
V.I. Pantyo \\ Cand. Sci. (Med.), Assoc. Prof. \\ Department of general surgery, Medical faculty \\ Uzhhorod National University \\ 3 Narodna Sq., Uzhhorod, 88000, Ukraine \\ tel: +38 (050) 532-56-22 \\ e-mail: pantyo@meta.ua \\ ORCID 0000-0003-2137-1567
}

\section{S.A. Gulyar}

Dr. Sci. (Med.), Prof., Leading Researcher

A.A. Bogomolets Institute of Physiology of NASU

4 Bogomoletz St., Kyiv, 01024, Ukraine

tel.: +38 (044) 253-20-13

e-mail: gulyar@zepter.ua

ORCID 0000-0003-2128-7656

\author{
G.M. Koval \\ Dr. Sci. (Med.), Prof., Head of the department \\ Department of microbiology, virology,epidemiology \\ with the course Infectious Diseases, Medical faculty \\ Uzhhorod National University \\ 3 Narodna Sq., Uzhhorod, 88000, Ukraine \\ tel: +38 (050) 372-85-59 \\ e-mail:prof.kovalgm@gmail.com \\ ORCID 0000-0002-0623-2326

\section{E.M. Danko} \\ Assistant \\ Department of therapeutic dentistry, Dentistry faculty \\ Uzhhorod National University \\ 3 Narodna Sq., Uzhhorod, 88000, Ukraine \\ tel: +38 (099) 090-79-90 \\ e-mail: elvira.danko@uzhnu.edu.ua \\ ORCID 0000-0002-3997-9311
}

Introduction. The problem of resistance to antimicrobial drugs continues to deteriorate, this is one of the greatest threats to health protection and for its solution active actions in different fields are required. Antibacterial drugs currently occupy one of the most important parts of the arsenal of drugs of medical institutions. Despite the natural sensitivity of Staphylococcus aureus to most antibiotics (beta-lactams, aminoglycosides, fluoroquinolones, macrolides, lincosamides, glycopeptides, rifampicin, etc.), its resistance to them grows intensively and substantially extend. Consequently, results of infections treatment caused by Staphylococcus aureus complicated and worsen. Among the solutions of the problem, special attention deserves the use of non-drug methods, in particular radiation of the optical range, to increase sensitivity of microorganisms to existing drugs. Due to proven positive influence on the human's body and almost complete absence of side eff and contra- indications, LED light application is a promising method.

Purpose of the work is to investigate direct effect and determine the optimum parameters of action of LED radiation of blue-red and red-infrared ranges on sensitivity to antibiotics of clinical isolates Staphylococcus aureus and test strain Staphylococcus aureus ATCC 25923.

Materials and methods. We studied the influence of LED radiation of red + infrared (MEDOLIGHT Red device) and blue + infrared (MEDOLIGHT BluDoc device) ranges on clinical isolates Staphylococcus aureus and collection test strain Staphylococcus aureus ATCC 25923 sensitivity to antibiotics. The radiation power density of the Medolight Red apparatus was $5.35 \mathrm{~mW} / \mathrm{cm}^{2}$, and the Medolight BluDoc apparatus was $10.15-8.2 \mathrm{~mW} / \mathrm{cm}^{2}$. The exposure time ranged from 5 to 25 minutes in increments of 5 minutes, and the frequency of radiation modulation was $0 \mathrm{~Hz} ; 10 \mathrm{~Hz} ; 600 \mathrm{~Hz} ; 3000 \mathrm{~Hz} ; 8000 \mathrm{~Hz}$. The dependence of radiation on the studied objects depending on exposure, wavelength and frequency were defined.

The result of photomodification on the state of microorganisms was increase of their sensitivity to some of the tested antibiotics. Based on the data obtained, we developed an algorithm and clinical recommendations for the use of LED radiation in the complex therapy of purulent-inflammatory diseases. LED emission of blue-IR range led to the most pronounced increase of sensitivity to ampicillin and oxacillin, while at red and infrared radiation - to levofloxacin, tetracycline and meroponem.

Key words: red, blue and infrared LED radiation, light modulation frequency, Medolight, Staphylococcus aureus devices, sensitivity to antibiotics. 


\title{
ВПЛИВ СВІТЛОДІОДНОГО ВИПРОМІНЮВАННЯ НА ЧУТЛИВІСТЬ STAPHYLOCOCCUS AUREUS ДО АНТИБІОТИКІВ
}

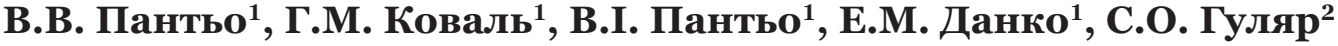 \\ ${ }^{1}$ ДВНЗ «Ужгородський національний університет», м. Ужгород, Украӥна; \\ ${ }^{2}$ Інститут фізіологї̈ імені О.О. Богомольця НАН Украӥни, м. Київ, Украӥна
}

Вступ. Проблема стійкості до протимікробних препаратів продовжує загострюватися, це одна з найсерйозніших загроз для здоров'я, і для іїі вирішення потрібні активні дії в різних областях. Антибактеріальні препарати в даний час є однією з найважливіших ланок в арсеналі лікарських засобів медичних установ. Незважаючи на природну чутливість Staphylococcus aureus до більшості антибіотиків (бета-лактами, аміноглікозиди, фторхінолони, макроліди, лінкозаміди, глікопептиди, рифампіцин та ін.), його стійкість до них інтенсивно зростає і суттєво розширюється. Отже, результати лікування інфекцій, викликаних Staphylococcus aureus, ускладнюються і погіршуються. Серед шляхів вирішення проблеми особливу увагу заслуговує використання немедикаментозних методів, зокрема опромінення оптичного діапазону спектру, для підвищення чутливості мікроорганізмів до існуючих ліків. Завдяки доведеному позитивному впливу на організм людини і практично повній відсутності побічних ефектів і протипоказань застосування світлодіодного світла є багатообіцяючим методом.

Метою роботи є дослідження прямого ефекту і визначення оптимальних параметрів впливу світлодіодного випромінювання синьо-червоного і червоно-інфрачервоного діапазонів на чутливість до антибіотиків клінічних ізолятів Staphylococcus aureus і тест-штаму Staphylococcus aureus ATCC 25923.

Матеріали і методи. Ми вивчили вплив світлодіодного випромінювання червоного + інфрачервоного (пристрій MEDOLIGHT Red) і синього + інфрачервоного (пристрій MEDOLIGHT BluDoc) на клінічні ізоляти Staphylococcus aureus і колекційний тестовий штам Staphylococcus aureus ATCC 25923 на чутливість до антибіотиків. Щільність потужності випромінювання апарату Medolight Red становила $5,35 \mathrm{mBт} / \mathrm{cm}^{2}$, а апарату Medolight BluDoc $-10,15-8,2 \mathrm{mBт} / \mathrm{cm}^{2}$. Час впливу становило від 5 до 25 хвилин 3 кроком 5 хвилин, а частота модуляції випромінювання становила 0 Гц; 10 Гц; 600 Гц; 3000 Гц; 8000 Гц. Визначено залежність випромінювання від досліджуваних об’єктів в залежності від експозиції, довжини хвилі і частоти.

Результатом фотомодифікації стану мікроорганізмів стало підвищення їх чутливості до деяких 3 протестованих антибіотиків. На підставі отриманих даних розроблено алгоритм і клінічні рекомендації щодо застосування світлодіодного випромінювання в комплексній терапії гнійно-запальних захворювань. Світлодіодне випромінювання інфрачервоного діапазону дало поштовх до найбільш вираженого збільшення чутливості до ампіциліну та оксациліну, а при червоному і інфрачервоному випромінюванні - до левофлоксацину, тетрацикліну і меропонему.

Ключові слова: червоне, синє і інфрачервоне світлодіодне випромінювання, частота модуляції світла, Medolight пристрої, Staphylococcus aureus, чутливість до антибіотиків.

\section{ВЛИЯНИЕ СВЕТОДИОДНОГО ИЗЛУЧЕНИЯ НА ЧУВСТВИТЕЛЬНОСТЬ STAPHYLOCOCCUS AUREUS К АНTИБИОТИКАM}

\section{В.В. Пантьо ${ }^{1}$, Г.Н. Коваль ${ }^{1}$, В.И. Пантьо ${ }^{1}$, Э.М. Данко ${ }^{1}$, С.А. Гуляр ${ }^{2}$ \\ ${ }^{1}$ ГВУЗ «Ужгородский национальный университет», г. Ужгород, Украина; \\ ${ }^{2}$ Институт физиологии имени О.О. Богомольца НАН Украины, г. Киев, Украина}

Введение. Проблема устойчивости к противомикробным препаратам продолжает обостряться, это одна из самых серьезных угроз для здоровья, и для ее решения требуются активные действия в разных областях. Антибактериальные препараты в настоящее время занимают одно из важнейших звеньев в арсенале лекарственных средств медицинских учреждений. Несмотря на естественную чувствительность Staphylococcus aureus к большинству антибиотиков (бета-лактамы, аминогликозиды, фторхинолоны, макролиды, линкозамиды, гликопептиды, рифампицин и др.), его устойчивость к ним интенсивно возрастает и существенно расширяется. Следовательно, результаты лечения инфекций, вызванных Staphylococcus aureus, усложняются и ухудшаются. Среди решений проблемы особое внимание заслуживает использование немедикаментозных методов, в частности облучения оптического диапазона спектра, для повышения чувствительности микроорганизмов к существующим лекарствам. Благодаря доказанному положительному влиянию на организм человека и практически полному отсутствию побочных эффектов и противопоказаний применение светодиодного света является многообещающим методом.

Целью работы является исследование прямого эффекта и определение оптимальных параметров воздействия светодиодного излучения сине-красного и красно-инфракрасного диапазонов на чувствительность к антибиотикам клинических изолятов Staphylococcus aureus и тест-штамма Staphylococcus aureus ATCC 25923. 
Материалы и методы. Мы изучили влияние светодиодного излучения красного + инфракрасного (устройство MEDOLIGHT Red) и синего + инфракрасного (устройство MEDOLIGHT BluDoc) на клинические изоляты Staphylococcus aureus и коллекционный тестовый штамм Staphylococcus aureus ATCC 25923 на чувствительность к антибиотикам. Плотность мощности излучения аппарата Medolight Red cocтав-

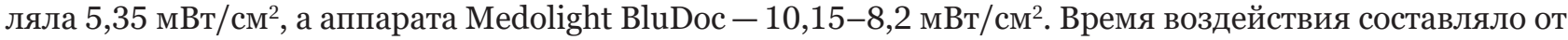
5 до 25 минут с шагом 5 минут, а частота модуляции излучения составляла 0 Гц; 10 Гц; 600 Гц; 3000 Гц; 8000 Гц. Определена зависимость излучения от исследуемых объектов в зависимости от экспозиции, длины волны и частоты.

Результатом фотомодификации состояния микроорганизмов стало повышение их чувствительности к некоторым из протестированных антибиотиков. На основании полученных данных разработан алгоритм и клинические рекомендации по применению светодиодного излучения в комплексной терапии гнойно-воспалительных заболеваний. Светодиодное излучение ИК-диапазона привело к наиболее выраженному увеличению чувствительности к ампициллину и оксациллину, а при красном и инфракрасном излучении - к левофлоксацину, тетрациклину и меропонему.

Ключевые слова: красное, синее и инфракрасное светодиодное излучение, частота модуляции света, Medolight устройства, Staphylococcus aureus, чувствительность к антибиотикам.

\section{Introduction}

The problem of resistance to antimicrobial drugs continues to deteriorate, this is one of the greatest threats to health protection and for its solution active actions in different fields are required [1,2]. Antibacterial drugs currently occupy one of the most important parts of the arsenal of drugs of medical institutions. From $25 \%$ to $35 \%$ of all hospitalized patients receive antibiotics according to various indications. At the same time, according to the WHO $50 \%$ of antibiotics are appointed without reason [1,3].

$S$. aureus is one of the main pathogens of skin and soft tissue diseases - boils, abscesses, cellulitis, phlebitis, mastitis, causing pneumonia, osteomyelitis, meningitis, endocarditis and others. Clinical strains of $S$. aureus are the most common microorganisms which are found in surgical patients $[4,5,6]$.

Despite the natural sensitivity of Staphylococcus aureus to most antibiotics (beta-lactams, aminoglycosides, fluoroquinolones, macrolides, lincosamides, glycopeptides, rifampicin, etc.), its resistance to them grows intensively and substantially extend. Consequently, results of infections treatment caused by Staphylococcus aureus complicated and worsen [5,7]. A significant concern evokes the emergence and spread of methicillin-resistant strains of Staphylococcus aureus (MRSA) that cause outbreaks of nosocomial and community-acquired infections [8].

Among the solutions of the problem, special attention deserves the use of non-drug methods, in particular radiation of the optical range, to increase sensitivity of microorganisms to existing drugs [9-14]. Due to proven positive influence on the human's body and almost complete absence of side effects and contraindications [10], LED light application is a promising method. It was also established that the microflora of the mouth can be affected by the light from halogen and LED sources, polarized and unpolarized. This reduces the number of bacterial colonies and their sizes, indicating to suppression or destruction of microbes [11]. But these data do not explain all the mechanisms of antimicrobial effects of light, which depend on its spectral characteristics, power density, frequency of impulses and polarization. Also important is to clarify possibilities of changes of some of the properties of microorganisms, in particular their sensitivity to damaging factors, such as antibiotics.

Purpose of the work is to investigate direct effect and determine the optimum parameters of action of LED radiation of blue-red and red-infrared ranges on sensitivity to antibiotics of clinical isolates Staphylococcus aureus and test strain Staphylococcus aureus ATCC 25923.

\section{Materials and methods}

We studied the effect of LED radiation of red and infra-red and blue and infrared ranges on sensitivity to antibiotics of clinical isolates of Staphylococcus aureus $(n=5)$ that were isolated from foci of inflammatory processes from surgical department patients of Uzhgorod CRH and collection test strain Staphylococcus aureus ATCC 25923.

Determining the impact of LED radiation on the sensitivity of microorganisms to antibiotics we used disco-diffusion method, according to current requirements of the Ministry of Health of Ukraine [15]. For this purpose, we took a pure 16-24-hour agar culture of microorganisms in a standardized liquid nutrient medium with concentration of $1.5 \times 10^{8}$ colony forming units (CFU) per $1 \mathrm{ml}$ (it meets the turbidity matching 0.5 Mcfarland standard) and reseeded on nutrient dense Mueller-Hinton medium in Petri dishes. Then we carried out exposure of microorganisms to LED radiation from a distance of $1 \mathrm{~cm}$ (Fig. 1), and then we superimposed discs with antibiotics and cultivated them in the incubator at $37^{\circ} \mathrm{C}$. Results were determined by measuring zones of microbial growth delay around the discs.

In order to exclude the impact of radiation on the growth properties of the nutrient media we carried LED radiation exposure of cultures that were in sterile Petri dishes separately and then replanted them in the culture medium and superimposed discs with antibiotics. 


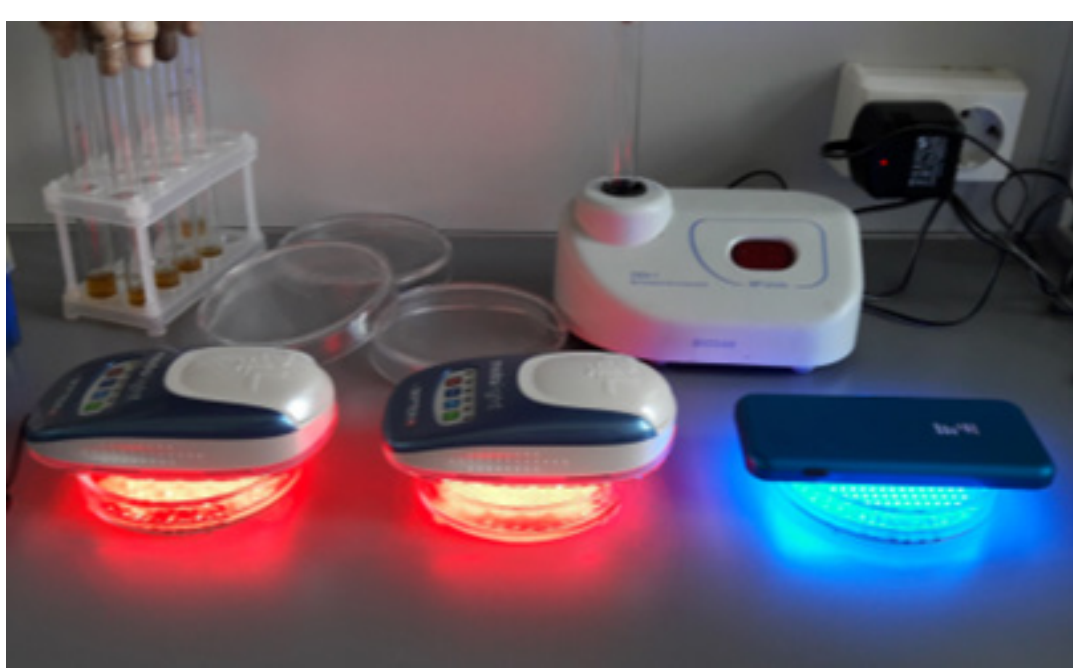

Fig. 1. Exposure of microorganisms to LED radiation (MEDOLIGHT Red and MEDOLIGHT BluDoc devices) in Petri dishes with nutrient medium
Thus, 5-minute exposure test strain of Staphylococcus aureus ATCC 25923 to LED emission of blue + infrared range with frequency of $0 \mathrm{~Hz}$ (continuous emission) increased its sensitivity to ampicillin, in average, for $15.5 \%$. Application of LED MEDOLIGHT BluDoc device radiation with exposure of 5 minutes and frequencies of 10,600, 3000 and $8000 \mathrm{~Hz}$ lead to increased sensitivity of Staphylococcus aureus ATCC 25923 to ampicillin for $12-13,5 \%$.

Fig. 3 shows increased sensitivity of Staphylococcus aureus ATCC 25923 to oxacillin after application of blue infrared range LED radiation.

Irradiation of Staphylococcus aureus ATCC 25923 by LED emission

We used sources of LED radiation, red and infrared (IR) $(640 \pm 30$ from $880 \pm 30 \mathrm{~nm})$ and blue and infrared $(470 \pm 30$ from $940 \pm 30 \mathrm{~nm})$ ranges, respectively, MEDOLIGHT Red and MEDOLIGHT BluDoc, production of Bioptron AG by Zepter Group. Light power density of MEDOLIGHT Red device did not exceed $5.35 \mathrm{~mW} / \mathrm{cm}^{2}$, and of MEDOLIGHT BluDoc it was $10.15-8.2 \mathrm{~mW} / \mathrm{cm}^{2}$ from a distance of $0-1 \mathrm{~cm}$. By separate series we examined the effect of exposures to LED radiation with different wavelengths $(5,10,15$, 20 and 25 minutes) and frequencies (0, 10, 600, 3000 and $8000 \mathrm{~Hz}$ ).

The results were compared with control series of not irradiated cultures. Also, in order to control the quality of microbiology investigations, in each series with clinical strains we used a collection test strain Staphylococcus aureus ATCC 25923 with known range values of microbial growth delays in areas of antibiotics influence.

We tested sensitivity of the research object to antibiotics of beta-lactam group, macrolides, fluoroquinolones, aminoglycosides, and vancomycin, which are included in the list of recommended antibiotics to determine sensitivity of Staphylococcus spp. [15].

\section{Results and discussion}

We established that the LED radiation increased the sensitivity of clinical isolates of $S$. aureus and collection of test strain $S$. aureus ATCC 25923 to some antibiotics (compared with non-irradiated cultures). In this case, the effect of influence depended on the wavelength, exposure duration and frequency of radiation. The most pronounced sensitivity increase was observed when irradiation exposure of microorganisms lasted for 5 minutes.

Fig. 2 illustrates the effect of 5-minute exposure to MEDOLIGHT BluDoc LED device at different frequencies on sensitivity of $S$. aureus ATCC 25923 to ampicillin and other antibiotics.

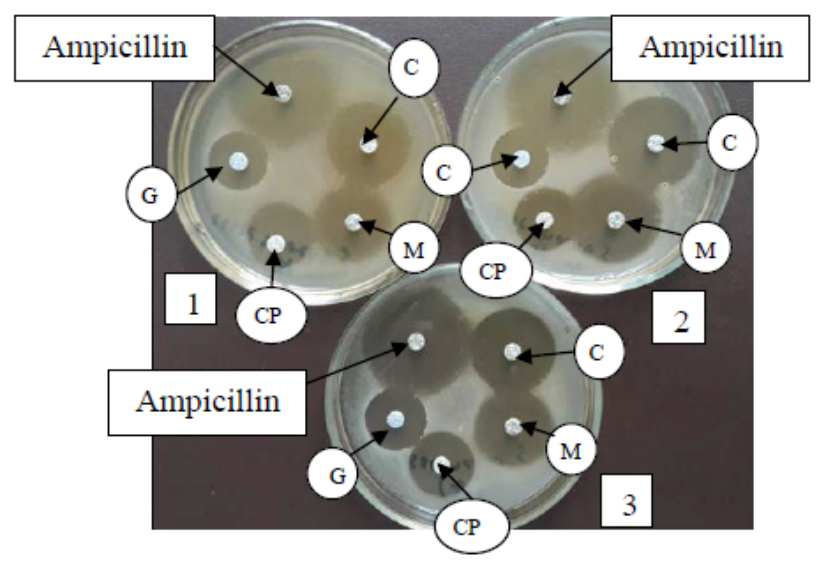

Fig. 2. Impact of LED irradiation of Medolight BluDoc device on sensitivity of $S$. aureus ATCC 25923

to antibiotics (exhibition $5 \mathrm{~min}$ )

1 - control; 2 - radiation with frequency of $0 \mathrm{~Hz}$; 3 - radiation with frequency of $10 \mathrm{~Hz}$;

C-cefotaxime; $M$ - meroponem;

$\mathrm{CP}$ - cefepime; G-gentamicin

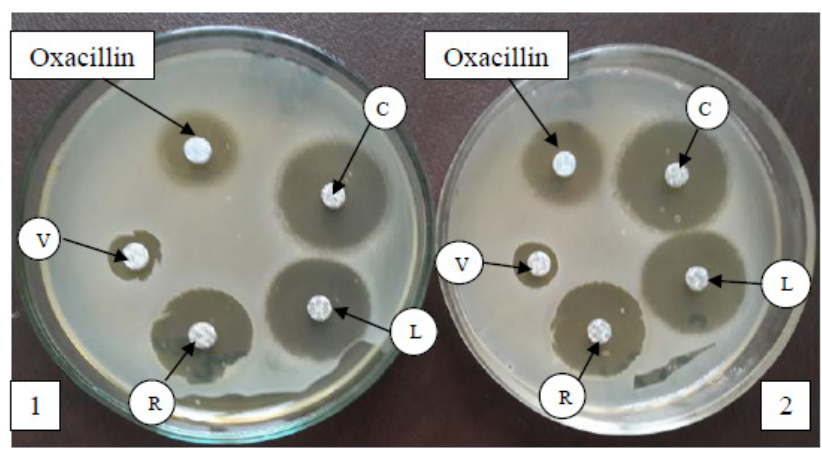

Fig. 3. LED irradiation effect of Medolight BluDoc device on antibiotics S. aureus ATCC 25923 (exhibition $5 \mathrm{~min}$ )

1 - control; 2-radiation with frequency of $0 \mathrm{~Hz}$;

C-cefotaxime; L-levofloxacin;

$\mathrm{R}$-rifampicin; V-vancomycin 
of blue + IR range with frequency of $0 \mathrm{~Hz}$ for 5 minutes increased its sensitivity to oxacillin by an average of $23.5 \%$. After similar exposure with frequencies of 10, 600, 3000 and $8000 \mathrm{~Hz}$ we observed increase of sensitivity of these strains to oxacillin - by 17-22\%.

Fig. 4 illustrates graphically the rate of sensitivity increase to ampicillin and oxacillin of Staphylococcus aureus ATCC 25923 under the influence of LED radiation of Medolight BluDoc device of different frequencies with 5 minutes exposure.

Table 1 shows statistically processed results of the impact of LED blue infrared radiation on sensitivity of $S$. aureus ATCC 25923 to ampicillin and oxacillin.

Using the LED irradiation of red + IR range led to a significant increase in sensitivity of studied strains $S$. aureus to levofloxacin (group fluoroquinolones), meroponem (group carbapenems) and tetracycline (group of the same name) (Fig. 5).

Thus, LED red + IR irradiation with exposure of 5 minutes at a frequency of $0 \mathrm{~Hz}$ resulted in increased sensitivity of $S$. aureus ATCC 25923 to levofloxacin by an average of $17 \%$, tetracyclin - by $27 \%$ and meroponem - by $22.47 \%$. After similar exposure with frequencies of $10,600,3000$ and $8000 \mathrm{~Hz}$ we observed an increase of sensitivity of $S$. aureus ATCC 25923 to levofloxacin by an average of $11-12,5 \%$, to tetracycline - by $21-23 \%$ and to meroponem - by $14-16 \%$ ( Fig. 6).

In Table 2 we present statistically processed results of the effects of LED red + IR radiation on sensitivity of $S$. aureus ATCC 25923 to levofloxacin, tetracycline and meroponem.

It should also be noted that after application of LED radiation with 5 minutes' exposition, we observed increased sensitivity of the examined microflora also to such antibiotics as cefotaxime, rifampicin and meroponem for 6.5-12\%, depending on the wavelength and frequency of light.

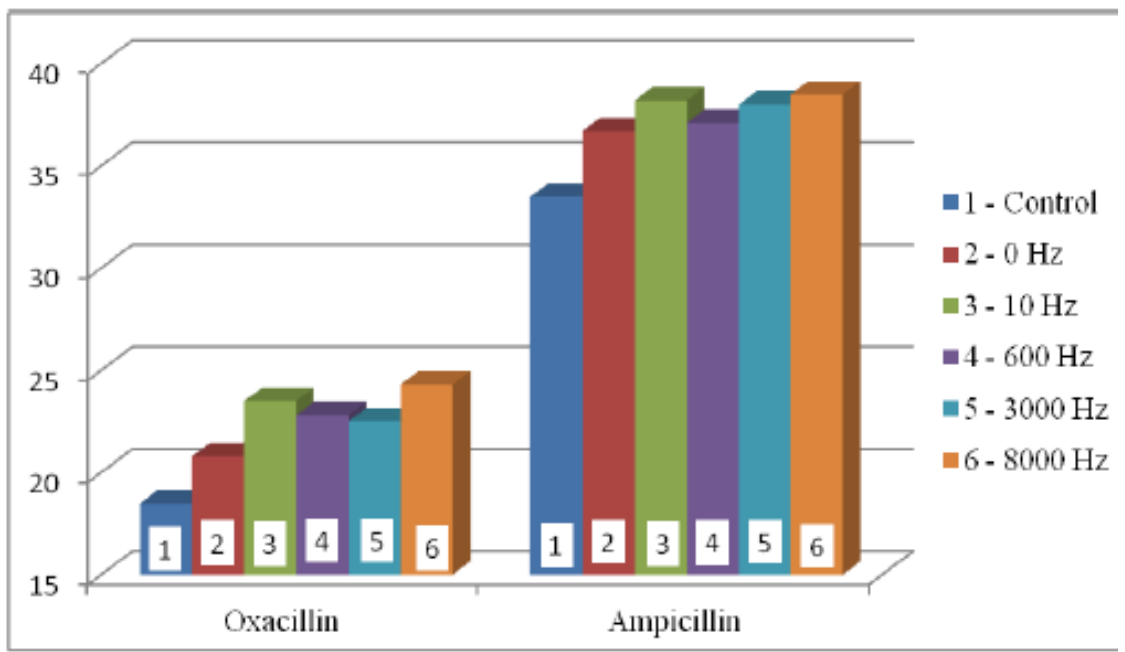

Fig. 4. Effect of blue+IR LED range emission on the value of stunted growth of S. aureus ATCC 25923

On the vertical axis - diameter of zones of stunted growth, $\mathrm{mm}$

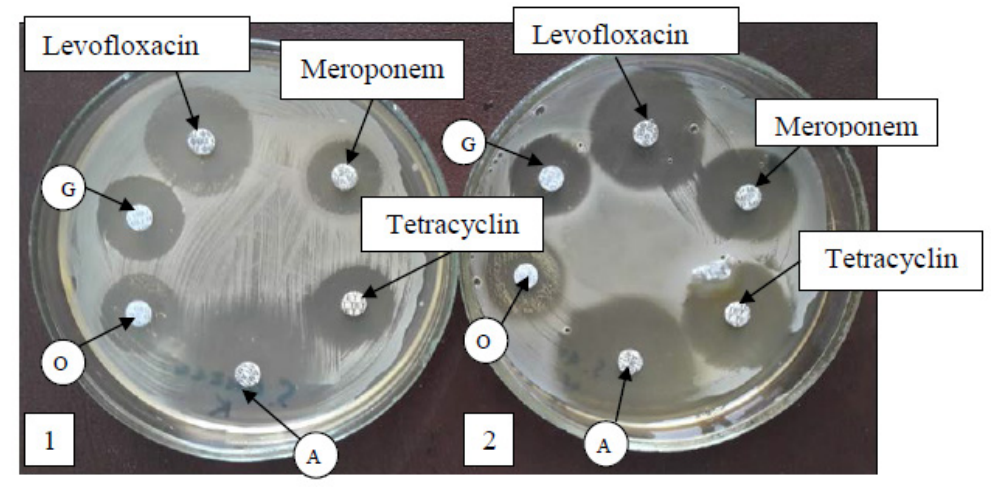

Fig. 5. Impact of LED radiation of Medolight Red device on sensitivity to antibiotics of $S$. aureus (5 min exposure)

1 - control; 2-radiation with frequencies of $0 \mathrm{~Hz}$; A - ampicillin; $\mathrm{O}$-oxacillin; $\mathrm{G}$ - gentamicin

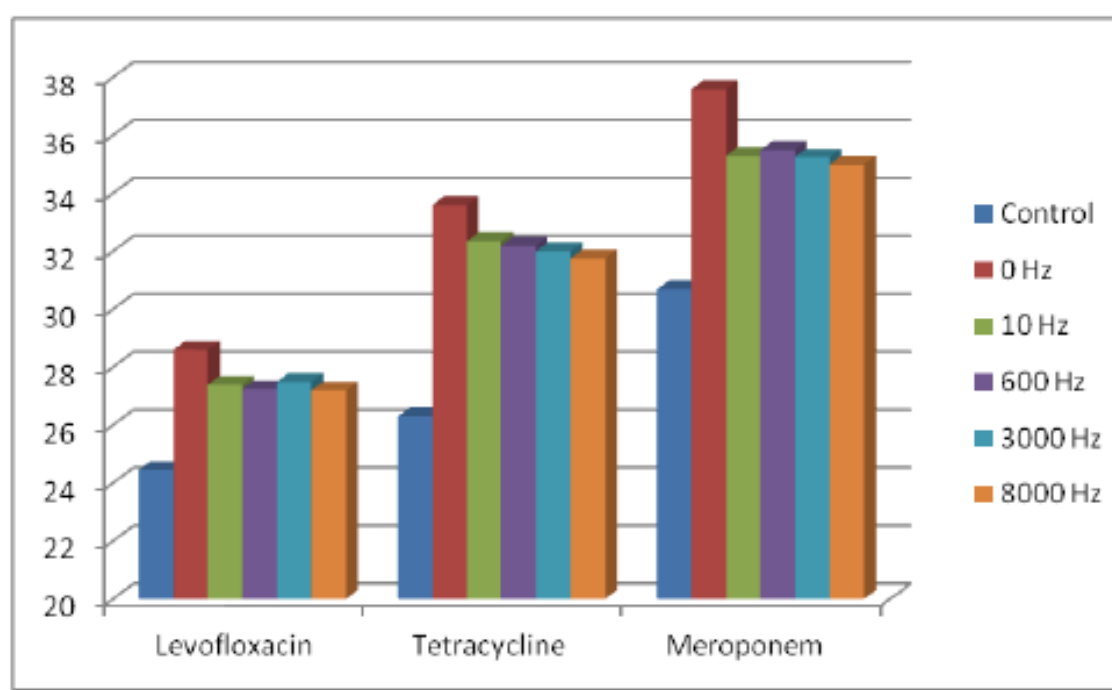

Fig. 6. Impact of LED radiation of red and infrared ranges on the size of areas of stunted growth of S. aureus ATCC 25923 
Diameters of the stunted growth zones of control and irradiated by LED blue + IR culture of S. aureus ATCC 25923

\begin{tabular}{|c|c|c|c|c|c|c|}
\hline \multirow[b]{2}{*}{ Antibiotic } & \multirow{2}{*}{$\begin{array}{l}\text { Control } \\
(n=10)\end{array}$} & \multicolumn{5}{|c|}{ Irradiation by LED radiation with exposure of 5 minutes } \\
\hline & & $\begin{array}{l}\text { Frequency } 0 \mathrm{~Hz} \\
\qquad(\mathrm{n}=10)\end{array}$ & $\begin{array}{c}\text { Frequency } 10 \mathrm{~Hz} \\
(\mathrm{n}=10)\end{array}$ & $\begin{array}{l}\text { Frequency } 600 \mathrm{~Hz} \\
\qquad(\mathrm{n}=10)\end{array}$ & $\begin{array}{l}\text { Frequency } 3000 \mathrm{~Hz} \\
\qquad(\mathrm{n}=10)\end{array}$ & $\begin{array}{c}\text { Frequency } 8000 \mathrm{~Hz} \\
(\mathrm{n}=10)\end{array}$ \\
\hline Ampicillin & $32,8 \pm 1,7$ & $\begin{array}{l}37,9 \pm 1,4 \\
(P<0,001)\end{array}$ & $\begin{array}{l}36,7 \pm 1,5 \\
(P<0,001)\end{array}$ & $\begin{array}{l}37,1 \pm 1,5 \\
(P<0,001)\end{array}$ & $\begin{array}{l}36,9 \pm 1,3 \\
(P<0,001)\end{array}$ & $\begin{array}{l}37,2 \pm 1,4 \\
(P<0,001)\end{array}$ \\
\hline Oxacillin & $19,1 \pm 1,1$ & $\begin{array}{l}23,6 \pm 1,4 \\
(P<0,001)\end{array}$ & $\begin{array}{l}23,0 \pm 1,1 \\
(P<0,001)\end{array}$ & $\begin{array}{l}23,2 \pm 0,6 \\
(P<0,001)\end{array}$ & $\begin{array}{l}23,3 \pm 0,9 \\
(P<0,001)\end{array}$ & $\begin{array}{l}22,5 \pm 0,9 \\
(P<0,001)\end{array}$ \\
\hline
\end{tabular}

Diameters of the stunted growth zones of the control and irradiated samples by LED red and infrared radiation ranges of the culture S. aureus ATCC 25923

\begin{tabular}{|c|c|c|c|c|c|c|}
\hline \multirow[b]{2}{*}{ Antibiotic } & \multirow{2}{*}{$\begin{array}{l}\text { Control } \\
(n=10)\end{array}$} & \multicolumn{5}{|c|}{ Irradiation by LED radiation with exposure of 5 minutes } \\
\hline & & $\begin{array}{l}\text { Frequency } 0 \mathrm{~Hz} \\
\quad(\mathrm{n}=10)\end{array}$ & $\begin{array}{c}\text { Frequency } 10 \mathrm{~Hz} \\
(\mathrm{n}=10)\end{array}$ & $\begin{array}{c}\text { Frequency } 600 \mathrm{~Hz} \\
(\mathrm{n}=10)\end{array}$ & $\begin{array}{c}\text { Frequency } 3000 \mathrm{~Hz} \\
(\mathrm{n}=10)\end{array}$ & $\begin{array}{c}\text { Frequency } 8000 \mathrm{~Hz} \\
(\mathrm{n}=10)\end{array}$ \\
\hline Levofloxacin & $24,45 \pm 1,3$ & $\begin{array}{c}28,6,9 \pm 1,2 \\
(P<0,001)\end{array}$ & $\begin{array}{l}27,4 \pm 1,6 \\
(P<0,01)\end{array}$ & $\begin{array}{c}27,25 \pm 1,45 \\
(P<0,001)\end{array}$ & $\begin{array}{l}27,5 \pm 1,2 \\
(P<0,001)\end{array}$ & $\begin{array}{l}27,2 \pm 0,9 \\
(P<0,001)\end{array}$ \\
\hline Tetracycline & $26,3 \pm 2,1$ & $\begin{array}{c}33,6 \pm 1,95 \\
(P<0,01)\end{array}$ & $\begin{array}{l}32,4 \pm 2,1 \\
(P<0,01)\end{array}$ & $\begin{array}{l}32,2 \pm 2,4 \\
(P<0,01)\end{array}$ & $\begin{array}{l}32,0 \pm 2,0 \\
(P<0,01)\end{array}$ & $\begin{array}{c}31,75 \pm 2,45 \\
(P<0,01)\end{array}$ \\
\hline Meroponem & $30,7 \pm 1,3$ & $\begin{array}{l}37,6 \pm 1,7 \\
(P<0,001)\end{array}$ & $\begin{array}{l}35,3 \pm 1,7 \\
(P<0,001)\end{array}$ & $\begin{array}{l}35,5 \pm 0,75 \\
(P<0,001)\end{array}$ & $\begin{array}{l}35,25 \pm 1,5 \\
(P<0,001)\end{array}$ & $\begin{array}{c}35 \pm 1,05 \\
(P<0,001)\end{array}$ \\
\hline
\end{tabular}

This regularity also concerned clinical isolates. 5-minute exposure to LED radiation increased sensitivity of all strains of $S$. aureus, cultured from locus of inflammatory diseases to ampicillin, oxacillin, cefotaxime, meroponem and rifampicin, and in some cases also to gentamicin and tetracycline.

Assessing the effects of irradiation of microorganisms in sterile cups, we noted the same regularities as after irradiation of bacteria in Petri caps with Hinton-Mueller agar, which allows to eliminate the impact of light on the properties of nutrient medium. Thus, the obtained results are related with the direct impact of photo modifying LED radiation on the examined flora.

Prolonged exposure of microorganisms to irradiation did not lead to the increase of their sensitivity, compared with 5-minute exposure. On the contrary, when irradiation lasted more than 15 minutes, sensitivity of all the investigated strains was within the statistical error compared with the control.

Taking in consideration almost complete absence of contraindications to the use of LED radiation, it can be used in the treatment of superficial suppurative inflammatory diseases caused by Staphylococcus aureus. This will allow to increase the effectiveness of antibiotics therapy for these infections.

\section{Conclusions}

LED radiation of red $+\mathrm{IR}(640 \pm 30$ and $880 \pm 30 \mathrm{~nm})$ and blue $+\mathrm{IR}(470 \pm 30$ and $880 \pm 30 \mathrm{~nm})$ ranges makes photo modifying impact on the investigated strains of Staphylococcus aureus, which manifests itself in increase of their sensitivity to most tested antibiotics.

The degree of influence depends on the wavelength, duration and frequency of radiation impulses - the most pronounced increase of sensitivity was noted at the exposure of 5 minutes at frequency of 0 $\mathrm{Hz}$ (continuous radiation).

LED emission of blue-IR range led to the most pronounced increase of sensitivity to ampicillin and oxacillin, while at red and infrared radiation - to levofloxacin, tetracycline and meroponem.

\section{References}

1. Antimicrobial resistance. World Health Organisation (Media centre). 2016. Available at: http://www.who.int/ mediacentre/factsheets/fs194/en/

2. The evolving threat of antimicrobial resistance: options for action. World Health Organisation. 2012. 125 p.

3. Dykyj OG. Modern aspects of antibiotics. 2013. Part 1, Resistance to antibiotics. Available at: http://www.asz. org.ua/index.php/study/274-suchasni-aspekti-zastosu- 
vannja-antibakterialnih-preparativ-chastina-1-rezistentnist-do-antibakterialnih-preparativ.html

4. Pantyo VI, Pantyo VV, Koval GM. Optimizacion of treatment of the patients, suffering neuropathically-infected form of the diabetic foot syndrome, using the iodine preparations and low-intensive laser irradiation. Klinichna khirurhiia. 2017;2:50-3.

5. Pantyo VV, Koval GM, Pantyo VI. Clinic-experimental study of impact of low-intensive laser irradiation on course of purulent-inflammatory processes, caused by Staphylococcus aureus. Klinichna khirurhiia. 2016;7: 43-5.

6. Salmanov AG. Antimicrobial resistance and healthcare-associated infections in Ukraine Epidemiological report of the multicenter study (2010-2014). Kyiv: Agrar Media Group. 452 p.

7. Nazarchuk OA, Nazarchuk GG, Paliy DV, Suhlyak VV. The sensitivity of Staphylococcus aureus clinical strains to antibacterial agents. Ukrainian medical journal. 2012;3(89):107-9.

8. DeLeo FR, Otto M, Kreiswirth BN, Chambers HF. Community-associated methicillin-resistant Staphylococcus aureus. The Lancet. 2010;375(9725):1557-68.

9. Afonina IA, Kraeva LA, Tceneva GY. [Effect of laser light polarization on the change of sensitivity to antibiotics of different groups of microorganisms]. In: Korobov AM, editor. XXXV Mezhdunar. nauchno-prakt. konfer. Primenenie lazerov v meditsine i biologii [The XXXV Internat. Sciens.-Pract. Conf. Application of Lasers in Medicine and
Biology]; 2011 May 25-28; Kharkov. Kharkov: Petrov Publ; 2011. p. 159-61.

10. Gulyar SA, Kosakovskyi AL, editors. Bioptron-PILER-light application in medicine. 2nd ed. Kyiv: Bogomoletz Institute of Physiology at the National Academy of Sciences of Ukraine: 2011. 256 p. (in Russian)

11. Gulyar SA, Ukrainskaya EA, Lesik GI, Tolochina OF, Chalenko YuV. Poly- and monochromatic light influence on microorganisms growth in hard nutrient mediums and its clinical significance at periodontitis. Anthology of light therapy. Medical Bioptron technologies. Kyiv: Bogomoletz Institute of Physiology at the National Academy of Sciences of Ukraine; 2009; p. 802-24.

12. Pantyo VV, Nikolaychuk VI, Pantyo VI. The influence of low intensive laser radiation on biological objects and sensibility to antibacterial agents. Photobiology and photomedicine. 2010;1, 2:80-7.

13. Pantyo VV, Koval GM, Pantyo VI. The influence of low intensity laser radiation on sebsitivity to antibiotics of Pseudomonas aeruginosa. ScienceRise. Biological science. 2016;2:18-24.

14. Radchenko O, Stepura L, Gamaleia N. Photodynamic inactivation of gram positive and gram negative bacteria in vitro with photosensitizer methylene blue. Photobiology and photomedicine. 2015;1, 2:29-33.

15. Approving the guidelines «Determination of the sensitivity of microorganisms to antibiotics» (2007). The Ministry of Health of Ukraine, 167. 